\title{
Protein C Deficiency Disease
}

National Cancer Institute

\section{Source}

National Cancer Institute. Protein C Deficiency Disease. NCI Thesaurus. Code C99025.

A rare thrombophilia disorder characterized by deficiency of protein C. It results in venous thromboembolism. 